\title{
Age, sex, and ischaemic heart disease as prognostic indicators in long-term cardiac pacing
}

\author{
W. R. FITZGERALD ${ }^{1}$, I. M. GRAHAM², T. COLE AND D. W. EVANS \\ From the Regional Cardiac Unit, Papworth Hospital, Cambridge
}

SUMMARY The influence of age, sex, and overt ischaemic heart disease on survival after pacing was studied in a population of 427 patients. The median survival for the whole group was $7 \cdot 75$ years. Women between 55 and 74 years and men between 65 and 74 years enjoyed median survivals in excess of 10 years. Patients over 74 years and men with ischaemic heart disease had median survivals of the order of 5 years and $3 \frac{1}{2}$ years, respectively. The findings may help to match generator lifetimes to patient-survival prospects.

The advent of long-life pulse generators coincided with increased awareness of the need for economic use of resources and suggested the need to identify patients whose prognosis for survival may make them unsuitable candidates for the more expensive units. A study of the patients paced at this centre over a 10-year period was therefore undertaken, the principal objectives being the assessment of effects on survival of characteristics readily identifiable at the time when a decision on choice of generator has to be made.

\section{Patients and methods}

The 427 patients, in whom permanent endocardial pacing systems were first implanted between 1 September 1967 and 31 August 1977, form the basis of the study. Their age and sex distribution is shown in Table 1 . The youngest patient was 6 years old at the time of implantation and the oldest 92. None had life-threatening extracardiac disease. Fifty-seven

Table 1 Age and sex distribution of patients

\begin{tabular}{lcc}
\hline Age $(y)$ & Men & Women \\
\hline$<55$ & 19 & 19 \\
$55-64$ & 51 & 29 \\
$.65-74$ & 94 & 62 \\
$>74$ & 71 & 82 \\
Total & 235 & 192 \\
\hline
\end{tabular}

1Present address: Royal Air Force Hospital, Ely, Cambs.

'Present address: Cardiac Department, St Vincent's Hospital, Elm Park, Dublin 4

Received for publication 25 October 1978 of the men and 33 women had ischaemic heart disease as evidenced by a clear history of angina pectoris and/or myocardial infarction. Inadequate numbers or insufficiently reliable data precluded interest in other characteristics which might have influenced survival.

Asynchronous pacemaker systems were used routinely until 1972 (75 patients) but since then it has been standard practice to install venticularinhibited ('demand') generators and only 21 patients received 'fixed-rate' units at first implantation. Many were subsequently converted to 'demand' pacing but 44 retained asynchronous systems until the end of the study. The indications for pacing were symptomatic complete heart block or sinuatrial disorder (26 patients).

Patients were seen for follow-up at intervals of 6 months or less. When patients could not attend one of the pacing clinics held throughout the Region, they were visited at home by technicians. For the purposes of this study, the end-point was the date of the last technical check or of death. The cause of death was sought from necropsy reports or from the last known medical attendant.

Life tables were compiled by the method of Peto et al. (1977).

\section{Results}

One hundred and two patients died ( 36 women and $66 \mathrm{men})$. Four of these $(0.9 \%$ of those paced) died in the immediate postoperative period. The cause of death was ascertained in 46 other instances; in 37 it was cardiovascular (acute myocardial infarction in 14 , congestive failure in 12 ) and in 5 it was neoplastic. In only 5 was there considered to be a possibility 
Table 2 Median survival in years

\begin{tabular}{lcc}
\hline Age at implantation & Men & Women \\
\hline$<55$ & $>10$ & $7 \cdot 5$ \\
$55-64$ & $6 \cdot 5$ & $>10$ \\
$65-74$ & $>10$ & $>10$ \\
$>74$ & $4 \cdot 75$ & 5 \\
Total & $7 \cdot 5$ & 9 \\
\hline
\end{tabular}

that pacemaker malfunction or competition was involved.

Table 2 shows the median survival, by age and sex, after first implantation of a permanent pacing system. Only those over the age of 74 years proved to enjoy a median survival of less than 6 years. Fig. 1 depicts the results of life-table analysis of the whole study group. Their survival is not significantly different from that of the age- and sex-matched East Anglian population in general (Registrar General, 1973). However, those under 55 years at the time of implantation of the first pacemaker system fared worse $(P<0.001)$ as did men in the 55 to 64 years age-group $(P<0.001)$. Fig. 2 shows the different survival experience of the sexes, women with pacemakers faring better than men $(P<0.05)$. Fig. 3 shows the poorer survival of those with ischaemic heart disease, compared with those not known to have it $(P<0.001)$. The median survival of women in this group was 7.5 years but of men only 3.5 years. Table 3 summarises the significant differences

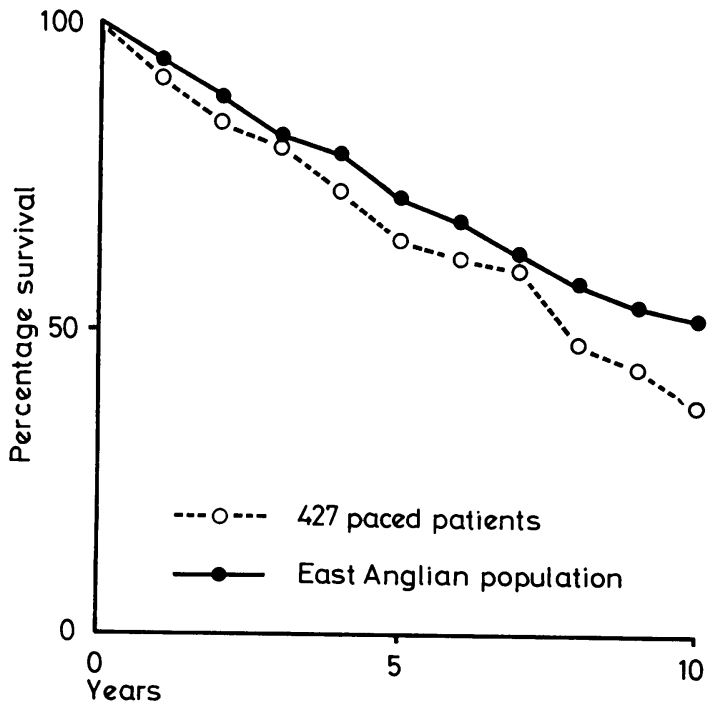

Fig. 1 Survival, by life-table analysis, of the 427 'paced' patients compared with that of an age and sex matched East Anglian population.

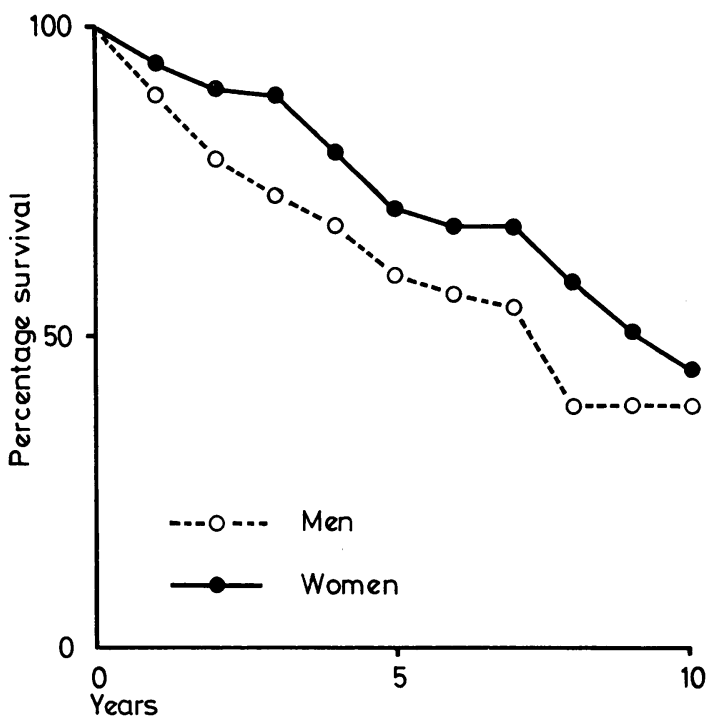

Fig. 2 Comparative survival of the men and women with pacemakers.

found in relative death rates between the subgroups and matched East Anglian populations.

\section{Discussion}

The median survival, for the whole study group, of 7.75 years is in line with reported experience of patients paced for heart block (Sowton and Flores, 1971; Simon, 1976; Stoney et al., 1977) and sug-

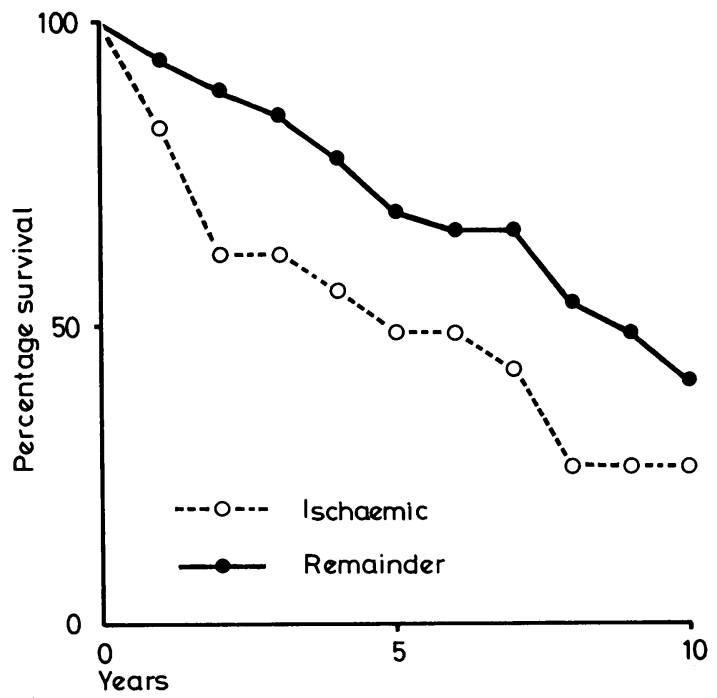

Fig. 3 Comparative survival of those with ischaemic heart disease and the remainder of the study population. 
Table 3 Relative death rates of paced subgroups and comparable East Anglian population (=1)

\begin{tabular}{|c|c|c|c|c|}
\hline \multirow{2}{*}{$\begin{array}{l}\text { Compared groups } \\
\begin{array}{l}\text { Men (paced) } \\
<55 \text { (y) (paced) }\end{array}\end{array}$} & \multirow[b]{2}{*}{$\begin{array}{l}\text { Women (paced) } \\
\text { East Anglian } \\
\text { population }\end{array}$} & \multicolumn{2}{|c|}{$\begin{array}{l}\text { Relative death } \\
\text { rates }\end{array}$} & \multirow{2}{*}{$\begin{array}{l}P \\
<0.05 \\
<0.00^{1}\end{array}$} \\
\hline & & $\begin{array}{r}1 \cdot 24 \\
11 \cdot 42\end{array}$ & $\begin{array}{l}0 \cdot 74 \\
1\end{array}$ & \\
\hline $\begin{array}{l}\text { Men 55-64 (y) } \\
\text { (paced) }\end{array}$ & $\begin{array}{l}\text { East Anglian } \\
\text { population }\end{array}$ & 4.54 & 1 & $<0.001$ \\
\hline $\begin{array}{l}\text { All ischaemic } \\
\text { group (paced) }\end{array}$ & $\begin{array}{l}\text { Remainder of } \\
\text { group (paced) }\end{array}$ & $1 \cdot 88$ & $0 \cdot 80$ & $<.0001$ \\
\hline $\begin{array}{l}\text { Male ischaemic } \\
\text { group (paced) }\end{array}$ & $\begin{array}{l}\text { Remainder of } \\
\text { male group (paced) }\end{array}$ & $1 \cdot 83$ & $0 \cdot 79$ & $<0.001$ \\
\hline $\begin{array}{l}\text { Female ischaemic } \\
\text { group (paced) }\end{array}$ & $\begin{array}{l}\text { Remainder of } \\
\text { female group (paced) }\end{array}$ & 1.97 & 0.85 & $<0.05$ \\
\hline
\end{tabular}

gests an improvement on the natural prognosis (Cosby et al., 1966; Edhag and Swahn, 1976). The inclusion of some patients ( $6 \%$ of those paced) with sinuatrial disorder is unlikely to have improved the prognosis of the study group as a whole (Wohl et al., 1976; Shaw et al., 1978). Neither is the initial use of asynchronous generators likely to have had a statistically significant effect on survival (Siddons, 1974) though 'demand' systems are now preferred because of the frequency of emergent, potentially competitive, rhythms even in those apparently in stable, complete heart block at the time of generator implantation (Grover et al., 1974; Furman and Fisher, 1977).

In contrast with the findings of Amikam et al. (1976), this study indicates a better than average prognosis for women paced after the age of 54 years. The poorer (than normal) survival of the younger patients, and of men in the 55 to 64 year age group, may be the result of the common association of coronary artery disease with atrioventricular block in middle age (Ginks et al., 1978). The relatively good survival of the elderly is confirmed (Amikam et al., 1976; Rettig et al., 1977). A poor 10-year survival for those over 74 years (Stoney et al., 1977) is not surprising as only 50 per cent of a normal equivalent population may be expected to survive for 6 years.

In this study, patients over 74 years comprised one of only two subgroups of patients with median survival periods of less than 6 years after first (permanent) pacing. The other was the group of men with overt ischaemic heart disease. These findings accord with those of Simon and Zloto (1978) who were also able to identify hypertensive heart disease and congestive failure as indicators of a poorer prognosis. The malign significance of heart failure has recently been highlighted by Hetzel et al. (1978).

Patients free from these stigmata, and under 75 years of age, might now reasonably be regarded as candidates for truly long-life pulse generators on both economic (Norman, 1976) and other grounds. For those with more limited survival prospectsnevertheless often of the order of 3 to 5 years in group median terms-less expensive generators with matched potential life-spans may be preferred.

We thank Mr Leslie Daly of the Department of Social and Preventive Medicine, University College, Dublin 4, for his help with the statistical analysis.

\section{References}

Amikam, S., Lemer, J., Roguin, N., Peleg, H., and Riss, E. (1976). Long term survival of elderly patients after pacemaker implantation. American Heart fournal, 91, 445-449.

Cosby, R. S., Lau, F., Rhode, R., Cafferky, E., and Mago, M. (1966). Complete heart block: prognostic value of electrocardiographic features and clinical complications. American fournal of Cardiology, 17, 190-193.

Edhag, O., and Swahn, A. (1976). Prognosis of patients with complete heart block or arrhythmic syncope who were not treated with artificial pacemakers. Acta Medica Scandinavica, 200, 457-463.

Furman, S., and Fisher, J. D. (1977). Cardiac pacing and pacemakers $\mathrm{V}$. Technical aspects of implantation and equipment. American Heart fournal, 94, 250-259.

Ginks, W., Siddons, H., and Leatham, A. (1978). Coronary artery disease as a cause of chronic disorders of impulse formation or propagation in middle age. In 1st European Symposium on Cardiac Pacing, p. 13. British Pacing Group, London.

Grover, F. L., O'Sullivan, M. J., and Fosburg, R. G. (1974). Demand or fixed-rate pacemakers? Eleven-year experience with 76 patients. Fournal of Thoracic and Cardiovascular Surgery, 67, 142-147.

Hetzel, M. R., Ginks, W. R., Pickersgill, A. J., and Leatham, A. (1978). Value of pacing in cardiac failure associated with chronic atrioventricular block. British Heart fournal, 40, 864-869.

Norman, J. (1976). Pacemakers: the long-term cost. Lancet, $1,88$.

Peto, R., Pike, M. C., Armitage, P., Breslow, N. E., Cox, D. R., Howard, S. V., Mantel, N., McPherson, K., Peto, J., and Smith, P. G. (1977). Design and analysis of randomized clinical trials requiring prolonged observation of each patient. II Analysis and examples. British fournal of Cancer, 35, 1-39.

Registrar General (1973). Statistical Review of England and Wales For the Year 1972. H.M.S.O., London.

Rettig, G., Doenecke, P., Schieffer, H., and Bette, L. (1977). Survival of elderly patients after pacemaker implant. American Heart Fournal, 94, 265-266.

Shaw, D., Gowers, J., Kekwick, C., and Bolwell, A. (1978). Mortality of patients with sinoatrial disorder (sick sinus syndrome). In 1st European Symposium on Cardiac Pacing, pp. 14-15. British Pacing Group, London.

Siddons, H. (1974). Deaths in long-term paced patients. British Heart fournal, 36, 1201-1209.

Simon, A. B. (1976). Atrioventricular block: natural history after permanent pacing. Circulation, 53 and 54, Suppl. II, 32.

Simon, A. B., and Zloto, A. E. (1978). Atrioventricular block: natural history after permanent ventricular pacing. American fournal of Cardiology, 41, 500-507. 
Sowton, E., and Flores, J. (1971). Natural history of pacemaker patients. Bulletin of the New York Academy of Medicine, 47, 999-1010.

Stoney, W. S., Finger, F. E., Alford, W. C., Burrus, G. R., Frist, R. A., and Thomas, C. S. (1977). The natural history of long term cardiac pacing. Annals of Thoracic Surgery, 23, 550-554.

Wohl, A. J., Laborde, J. L., Atkins, J. M., Blomqvist, C. G., and Mullins, C. B. (1976). Prognosis of patients permanently paced for sick sinus syndrome. Archives of Internal Medicine, 136, 406-408.

Requests for reprints to Dr D. W. Evans, Regional Cardiac Unit, Papworth Hospital, Papworth Everard, Cambridge CB3 8RE. 